\title{
The gender distribution of real property 1 ownership in late medieval Brussels 2 (1356-1460)
}

ABSTRACT. Although ownership of real property was crucial to the economic opportun- 5 ities of medieval urban women, few studies systematically investigate the gender distri- 6 bution of medieval real property over time. Using censiers (rarely used sources), this 7 article approaches this question through a socio-geographical analysis of Brussels. 8 The study finds that, despite the region's egalitarian inheritance laws, female owner- 9 ship of real property was relatively limited, and it declined during the late Middle 10 Ages. This decrease accelerated during economic crises, and especially affected the 11 property of non-elite women. Further research on the changing economic opportunities 12 of medieval women would benefit from a more explicit discussion of non-labour income 13 sources and social status.

As the ownership of landed property was a 'crucial aspect of the gendering of 16 space' in medieval society, most historians recognise the importance of prop- 17 erty ownership for women's position in late medieval cities. ${ }^{1}$ But while there 18 is an extensive body of literature on medieval women and property from a jur- 19 idical perspective, either with a prescriptive focus on law codes and legal 20 instruments, such as wills and marriage contracts, or on the presence of 21 women in law courts, ${ }^{2}$ other basic aspects of the relationship of urban 22 women to real property have received little attention. The actual percentage 23 of women among urban property holders remains difficult to determine, and 24 there are few studies of the participation of women in urban property and 25 capital markets beyond the anecdotal level. ${ }^{3}$ Sources on medieval property 26

* University of Leuven and University of Antwerp. 
markets are often lacking and analysing those that do survive is labour- 27 intensive and methodologically challenging. ${ }^{4}$ This article uses lists of real 28 estate owners called censiers, a source type that has often been neglected in 29 medieval urban history and women's history, ${ }^{5}$ to investigate the gendered dis- 30 tribution of real property in an urban setting and the change in this division 31 over time.

This data offers an original perspective on the longstanding debates about 33 late medieval changes in women's (economic) opportunities and inheritance 34 customs and their possible relation to the Black Death, because no scholar 35 has yet attempted to quantify the gendered distribution of late medieval 36 urban landownership systematically, or to examine long-term changes in this 37 distribution. ${ }^{6}$ For a more nuanced understanding of these changes, this study 38 uses spatial and socio-geographical analysis to compare neighbourhoods 39 with different social profiles. Moreover, this article relates its findings to com- 40 parable studies of other European regions, thus situating this research in a 41 comparative framework.

After briefly surveying the historiography, the article introduces the city of 43 Brussels and its property laws, as well as the methodology and sources. 44 Following this, I outline the ways that men and women appeared as land- 45 owners in the sources and compare the proportion of female landowners in 46 Brussels with that of other European regions, for example, southern France 47 and England. I argue that the proportion of women as landowners in 48 Brussels was relatively limited despite the region's egalitarian inheritance 49 laws, possibly because inheritance practices directed real estate to sons, and 50 women were more active as sellers than as buyers in the real estate market. 51 Next, I investigate changes in the gendered distribution of land ownership 52 over the late Middle Ages through a spatial analysis that compares women's 53 landownership in different neighbourhoods of the city. The evidence shows 54 that there was a clear and sustained decrease in the proportion of women 55 among Brussels landowners over the late medieval period, which confirms 56 the view that women's economic opportunities declined in the fourteenth 57 and fifteenth centuries. However, the decline was neither linear nor unambigu- 58 ous. Instead, the decline in female landownership was connected to years of 59 economic crisis and the social standing of women: difficult economic times 60 seem to have intensified the gender inequality in ownership patterns. Social 61 status intersected with gender in this process: the decline of female landowners 62 was especially concentrated in the poorer areas of the city, whereas the women 63 from the highest social groups seem to have held on to their real estate, as the 64 proportions remained relatively unaffected. This study concludes that the 65 social redistribution of urban property during years of economic crisis had 66 an important, and hitherto unrecognised, gendered dimension. 
2. WOMEN'S ECONOMIC STATUS AND LANDOWNERSHIP IN LATE MEDIEVAL

The changing position of women in the late medieval period has been the subject of particularly intense debates. One of the major issues is whether the economic participation of women changed during the fourteenth and fifteenth centuries, especially in north-western Europe, and, if so, how, when and why? Most historians agree that there was a gradual decline over this period because of changing production conditions and labour markets, the growing control of labour by male-dominated craft guilds, and erosion in the role of the household as a production unit, leading to the exclusion of women from high-status employment. With regard to property management, the increased emphasis of families on patrilineal preservation of family property led to limitations to female control of wealth. ${ }^{7}$ Specifically for the Low Countries, the fundamental work of Martha Howell on late medieval Douai showed how families became increasingly concerned with securing property along patrilineal family lines in the midst of increasing economic instability in the fifteenth century. In doing so, they gradually limited women's control of wealth. ${ }^{8}$

In opposition, other historians have argued for a more positive trend in the 85 position of women after the demographic crisis of the Black Death in the middle of the fourteenth century. For late medieval England, Jeremy Goldberg and Caroline Barron, along with others, are exponents of this view. ${ }^{9}$ Until recently, no scholars working on women in the urban Low Countries espoused this view, although historiography on women in the medieval Low Countries is not extensive. However, in a recent article on the Low Countries and England, Tine De Moor and Jan Luiten van Zanden contended that the demographic deficit after the Black Death gave rise to European marriage pattern in the late medieval Low Countries and England. Characterised by an older age at marriage for both partners and the predominance of nuclear households, this marriage pattern significantly empowered women in late medieval society for various reasons. De Moor and Van Zanden argued that 'only the upper layers of society ... were probably to a large extent immune from these changes' ${ }^{10}$ and concluded that women's position only began to deteriorate in the sixteenth century.

Although the chronology, causes and effects of the changes in the position 101 of late medieval women remain heavily debated topics, discussions have pre- 102 dominantly revolved around women's work. Other areas of economic oppor- 103 tunity, such as access to credit and property, are less often taken into account. 104 In addition, economic studies of the Low Countries rarely offer data or discus- 105 sion about women, and if they do, they focus on widows. ${ }^{11}$ Despite this void, 106 women's ownership of property was an important aspect of their economic 107 position. Owning real property substantially increased one's creditworthiness 108 
on capital markets. ${ }^{12}$ For the sale of annuities, one of the most important credit 109 instruments in this region, a mortgage on real property was either mandatory 110 (hereditary annuities) or the most common (life annuities) in the late Middle 111 Ages. ${ }^{13}$ Possessing real estate therefore opened up more economic opportun- 112 ities to these women, which could significantly improve their finances. 113 Furthermore, like labour, women's property ownership could change with 114 the demographic shifts in late medieval Europe. For example, studies of south- 115 ern France, where female inheritance rights were less favourable than in the 116 Low Countries, have shown that women's access to owning property improved 117 for a short period after the Black Death. ${ }^{14}$

Situated in the duchy of Brabant, the city of Brussels was one of the largest cit- 120 ies of the Low Countries, the most densely urbanised and commercialised region of late medieval Europe, along with northern Italy. In the late fifteenth century, 121 Brussels became the capital of the duchy and grew to include approximately 35,000 inhabitants. From the beginning, Brussels's success in trade, based largely on the luxury cloth industry, caused its growth. At the end of the fourteenth century, the cloth sector experienced a sharp decline, only partially countered by conversion to tapestry production. Meanwhile, Brussels gained increasing importance as it gradually became the political centre of the duchy. ${ }^{15}$

The spatial structure of Brussels offers significant context for discussion of property ownership. Spatial organisation is an important analytical factor, because the sources usually grouped property owners by parish and location inside or outside of the first city wall. Figure 1 is a map of Brussels showing the parishes and town walls. In 1356, the city of Brussels started to build its second town wall, which became the spatial border of the city and forms the boundary of this study. The new wall enclosed several suburbs that had grown up outside the first wall over the previous centuries. Consequently, the city's structure followed a typical concentric pattern, with the area between the two walls comprised of many residential areas and some semi-rural sections. The heart of the city's economy, the town hall, the cloth halls, and several markets, was located inside the first wall. The elite families of Brussels lived there, along with the duke of Brabant. Surrounded by residential areas, the ducal palace was located in the parish of the Coudenberg. During the late Middle Ages, there were six parishes in the city. Only one of those was situated entirely within the first city wall: the parish of St Nicolas. All the other parishes had one section inside the first city wall and another between the two walls.

All property within the walls of Brussels fell under the jurisdiction of the city's property laws. As in most towns in the region, Brussels's partible inheritance custom granted all children equal inheritance shares, regardless of their 148 


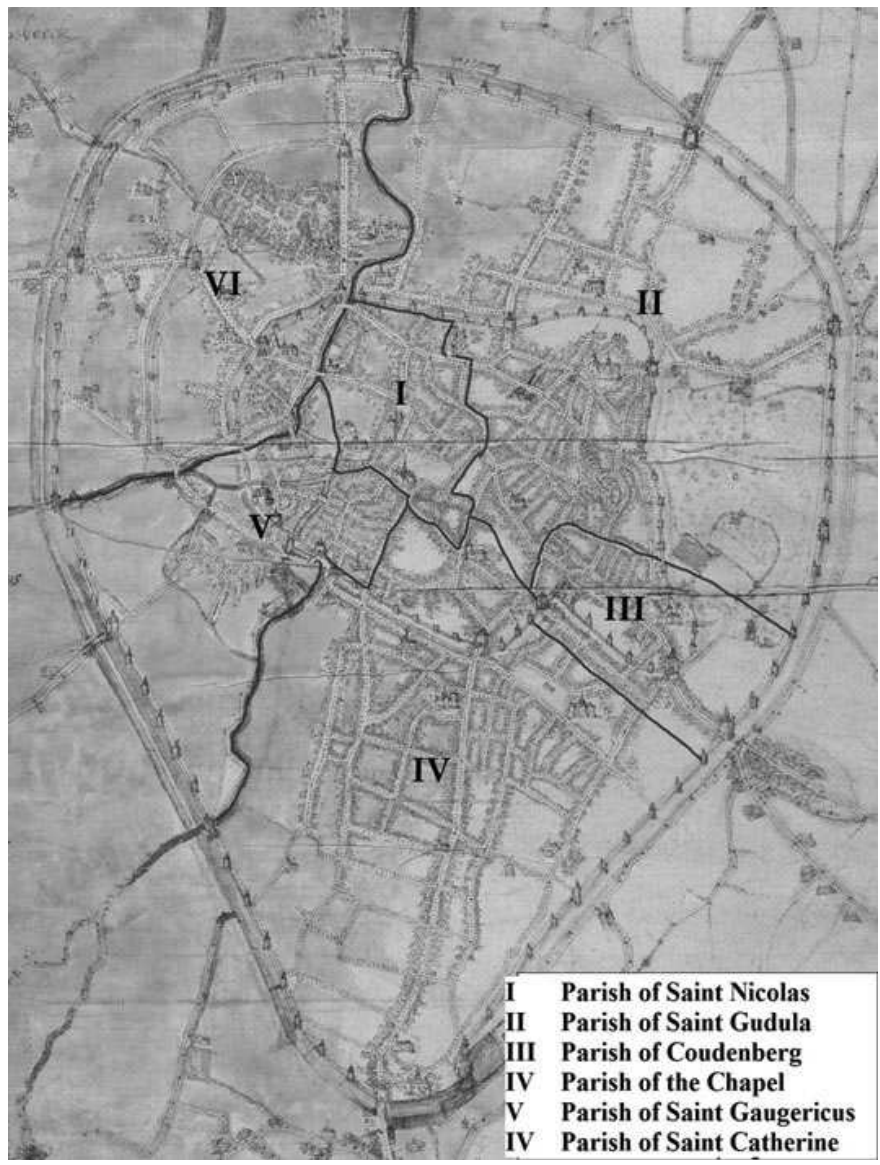

Figure 1. Brussels in the late Middle Ages, with indication of the six parishes (author's adaption of the city map of Jacob van Deventer, c. 1560). Source: Royal Library of Belgium, Kaarten en Plannen, Atlas des villes des Pays-Bas 1550-1565, fo. 15r. (C) Royal Library of Belgium.

age or sex, with the exception of property held in fief. The division in practice was made by mutual agreement, although one could go to the court of the 149 aldermen in case of conflict or to document the division. The actual composition of the inheritance shares could vary, as long as the entitled parties deemed them to be of equal value to one another. ${ }^{16}$ Upon marriage, children received an advance of their inheritance in the form of a marriage gift. Receiving a marriage gift didn't exclude women from inheriting their remaining share of the patrimony later in life, in contrast to dowered daughters in most southern European regions. ${ }^{17}$ The same equality was present in the provisions for widows and widowers, as both had the same rights to the marital estate; the survivor received all movable property, half of the real property held in the communal account, and usufruct, or lifetime use, of the remaining real property. The surviving spouse also enjoyed usufruct on the personal property of the deceased. During the marriage, a limited communal property regime prevailed. Each of the spouses remained the full owner of his or her 
personal property, consisting of real property obtained through gifts, testa- 164 ments, or inheritance. All other property - movable goods and real property 165 acquired during the marriage - was held in communal account. During her 166 marriage, a woman was considered legally incapable and could only perform 167 legal acts under guardianship of her husband. He controlled the marital estate 168 freely, except for his wife's personal property, which he could not manage or 169 alienate without her permission. ${ }^{18}$

However, there was some elasticity in the laws that defined the rights of 171 married women in Brussels; as a public merchant, a married woman was 172 not subject to guardianship in any matter that pertained to her own business, 173 she could enter freely into debts for household necessities, and she could 174 act as a substitute for her husband if he was absent or mentally ill. ${ }^{19}$ In add- 175 ition, studies of women in the medieval Low Countries have shown that the 176 custom of guardianship was not always followed and married women some- 177 times managed their own property without guardians, especially in the four- 178 teenth century. ${ }^{20}$ Finally, unmarried women and widows were considered 179 fully legally capable. In other words, city law allowed women a certain degree 180 of economic agency in Brussels, as in other Low Countries cities. Whether 181 women retained that agency was largely dependent on two factors: their mari- 182 tal status and their access to capital or property. While historians of the Low 183 Countries have concentrated on the first condition, this article will highlight 184 women's access to real property through analysis of the censiers.

'Le chemin est long; il n'est pas impracticable' were the closing words of Robert Fossier's typology of censiers, ${ }^{21}$ and they were no exaggeration; censiers are complicated sources. ${ }^{22}$ Perhaps for this reason, few historians who work on medieval cities are familiar with them. Daniel Lord Smail and Joëlle Rollo-Koster used censiers to study women in fourteenth-century Marseilles and Avignon, but in a more limited fashion than this study; both scholars assess the relative proportion of women, without taking marital status, spatial and chronological differences, and other variables into account. ${ }^{23}$ The intent of this article is to make the most of the censiers' potential: because these documents listed landowners who had to pay a yearly census to an institution, they can provide successive snapshots of (urban) property ownership patterns. Although they provide minimal information on medieval property owners, the sources have clear merits. First, censiers survive for regions and time periods for which there are few large collections of medieval property deeds (such as the northern Netherlands). Second, censiers allow for relatively rapid processing, as long as the historian understands their peculiarities and has developed a method to take these features into account, as I will discuss below. 
Systematic use of censiers (cijnsregisters in Dutch) requires a careful study 204 of the content and context, and a methodology that addresses the particular 205 features of each document. Censiers were administrative documents that listed 206 real property owners who had to pay a yearly cens (census or burgage rent) to 207 an institution or private person. ${ }^{24}$ These payments originated in several differ- 208 ent ways. Real estate, whether allodial or not, could be given in hereditary 209 ownership to a tenant for payment of a perpetual rent, which could sometimes 210 be redeemed. Any landowner might also sell a hereditary annuity on his or her 211 property for an amount of cash, in order to mobilise its capital value without 212 disposing of it. In this case, he or she pledged to pay a yearly annuity to the 213 buyer of the annuity (the creditor), which could be a private person or an insti- 214 tution. Finally, some feudal landlords collected recognition rents from land- 215 owners who fell under their feudal rights, such as the use of a street or river 216 (for example, the duke of Brabant collected these rents from house owners 217 who encroached on the Brussels public road by building a wall, or basement 218 entrance). While all types of rents are listed in the surveys, identification of the 219 type of rent is rarely possible. Scribes used a variety of interchangeable terms 220 to describe all types of rents, without being consistent, and the entries usually 221 focus on the payer, the payment, and the property.

The finer points of the property laws of late medieval Brabant are beyond 223 the scope of this article. However, it is important to emphasise that regardless of the way the cens was created, the payer in late medieval Brussels had extensive rights to the property. The payer or tenant can be considered as the actual landowner, as he or she could freely dispose of the property, build on it, lease it, mortgage it, or pass it on to heirs. When the property was alienated, the cens always remained bound to the property. As such, this study will refer to the payer of a cens as the 'cens payer' or 'owner'. On the other hand, the rights of the cens collector, called 'landlord' in this study, were limited to receipt of the payment itself. If the landowner repeatedly failed to make payments, the landlord was entitled to take legal action and repossess the property.

The sources for this study are 27 surveys composed between 1356 and $1460 .^{25}$ They were chosen from almost 80 censiers drawn up by Brussels institutions and individuals that have survived from the fourteenth and fifteenth centuries. $^{26}$ The following criteria informed the selection: the documents had to be dateable, to list property inside the city walls, and to be sufficiently extensive (listing more than 20 properties) and complete. The 27 censiers 237 selected were drawn up by 12 landlords: the duke of Brabant ( 3 surveys), 10 religious and charitable institutions (23 surveys), and one private individual (the patrician Jan van Aa, one survey).

Institutions and private landlords used censiers to administer and supervise the collection of their cens payments. Rather than conducting surveys on a 244 regular basis, rent collectors recorded these only when they deemed it 245 
necessary. Because of the survey's practical purpose, the information was 246 often standardised. A typical entry contained the name of the property 247 owner, additional information about him such as family members or profes- 248 sion, description of the property, the payment, and the payment due date 249 (s). ${ }^{27}$ The diligence of some administrators produced censiers with extensive 250 descriptions of the properties, while others only listed the name of the 251 owner and a vague delineation of the land. In short, these 27 censiers from 252 12 different institutions are not homogeneous, and this, along with their limited 253 information, causes the greatest methodological difficulties.

Analysis of censiers demands a methodology that addresses the particular fea- 255 tures of each censier. To construct a valid quantitative analysis from all the 256 selected censiers, information from the registers was collected and restructed 257 into the following well-defined categories: the cens payer(s) (male and female, 258 but only private individuals), ${ }^{28}$ the number of cens plots per payer, the way they 259 paid the census (independently, in a couple, or in a group), information about 260 the marital and social status of the payer(s), and the location of the property. 261 These data were collected by censier, and only dateable information was 262 included; names noted down by the clerks later were not included. Next, the 263 sequential censiers of each institution were compared. This was an extremely 264 important step, because not only did some institutions have different methods 265 of registration, but also the spatial distribution of the cens parcels differed for 266 each institution (this spatial distribution is called the cens circle, or the collection 267 of cens levied by an institution) and the intervals between successive censiers 268 were unique to each institution. The cens of one institution might be concen- 269 trated in the city centre, while another institution might levy cens predominantly 270 in the suburbs. Only in the final stage of the analysis, after considering the cens 271 circle of each institution, is it possible to compare registers from different insti- 272 tutions. This approach takes the administrative and geographical characteristics 273 of each survey and institution into consideration. Following this methodology, I 274 will treat these sources as sequential snapshots of landownership patterns in late 275 medieval Brussels. ${ }^{29}$

In the 27 censiers composed between 1356 and 1460, there were 6,975 land- 278 owners paying cens on 7,420 land plots, and some owners paid cens for sev- 279 eral parcels. Of these landowners, 13.9 per cent, or 967 persons, were 280 identifiable as female. There was a similar gender distribution for the 7,420 281 cens parcels, as Table 1 shows. Men paid cens for 84.3 per cent of the parcels, 282 a large majority, and women were responsible for 11.6 per cent. Groups of 283 men and/or women paid 2.2 per cent (163 cens). Most women owned a single 284 plot of land, but some women owned several parcels, and several groups of 285 
TABLE 1

Distribution of the cens by type of payer (1356-1460)

\begin{tabular}{lrr}
\hline \hline Type of payer & Number & $\%$ \\
\hline Men & 6,258 & 84.34 \\
Women & 858 & 11.56 \\
Groups & 163 & 2.20 \\
Unclear & 75 & 1.01 \\
Rest & 66 & 0.89 \\
Total & 7,420 & 100.00 \\
\hline \hline
\end{tabular}

Source: See Appendix Table 1.

women paid a cens together. The identities of the owners of the remaining 141286 $\begin{array}{ll}\text { parcels are unclear. }{ }^{30} & 287\end{array}$

Table 2 shows the way male and female landowners held their land, or at 288 least, the way the clerks registered them as cens payers. Eighty-one per cent 289 of women paid their cens independently. Men were more likely than women 290 to pay their cens independently, although the difference is rather small; 95291 per cent of the payments were made by a man on his own. In 16 per cent 292 of the payments (163 cens), women and men paid the sum together. Some 293 were married couples (65 cens), which might indicate that the property in 294 question belonged to the marital communal property owned by both spouses. 295 However, it is more probable that the clerks usually did not list both spouses if 296 communal property was involved; otherwise, one would expect a much larger 297 percentage of couples paying cens together. In the entries that list both hus- 298 band and wife, the cens was most likely attached to the wife's personal prop- 299 erty, and the clerks used this formulation to indicate that the woman was under 300 guardianship. A few explicit descriptions seem to indicate this, such as: 301 'Lijsbet Zwerten and Jan van den Driessche, her husband as her guardian.' 31302 Women and one or more male family members (often siblings or children) 303 paid ninety-eight cens, and fifteen cens were paid by groups of women, 304 often from the same family. Lastly, the category 'rest' includes people who 305 were paying a cens together with either their children or unidentifiable other 306 people (referred to as 'coparties' by the clerks). 307

Regarding the Low Countries and other regions of Europe, most studies of 308 medieval female real estate owners focus on widows. The reason for this is 309 well known; often it was only at this point in their lives that women had 310 autonomous access to capital and could act without the supervision of a guard- 311 ian. While we would thus expect to find a predominance of widows among the 312 967 women mentioned in the censiers, this is not the case, as Table 3313 
TABLE 2

Distribution of the cens paid by men and women, by mode of payment (1356-1460)

\begin{tabular}{lrrrrr}
\hline \hline & \multicolumn{2}{c}{ Men } & & \multicolumn{2}{c}{ Women } \\
\cline { 2 - 3 } Mode of payment & Number & $\%$ & & Number & $\%$ \\
\hline Alone & 6,117 & 95.27 & 832 & 81.49 \\
With a man & 132 & 2.06 & & 163 & 15.96 \\
With a woman & 163 & 2.54 & & 15 & 1.47 \\
Rest & 9 & 0.14 & & 11 & 1.08 \\
Total & 6,421 & 100.00 & & 1,021 & 100.00 \\
\hline \hline
\end{tabular}

Source: See Appendix Table 1.

TABLE 3

Marital status of female cens payers (1356-1460)

\begin{tabular}{lrr}
\hline \hline Marital status & Number & $\%$ \\
\hline Married & 190 & 19.65 \\
Partner & 22 & 2.28 \\
Widow & 118 & 12.20 \\
Religious & 7 & 0.72 \\
Unknown & 630 & 65.15 \\
Total & 967 & 100.00 \\
\hline \hline
\end{tabular}

Source: See Appendix Table 1.

illustrates. The clerks recorded that 22 per cent of the women were married, 12314 per cent were widows, and for remaining 65 per cent there was no marital sta- 315 tus given. Only seven women were identified as religious (either nun or 316 beguine). The absence of information on the marital status for 65 per cent 317 of the women should not be interpreted as a clear indication of the absence 318 of male family members or status as a widow. Rather, women in the Low 319 Countries were regularly identified without marital status: Shennan Hutton 320 found that 45 per cent of the women in the aldermen's registers of fourteenth- 321 century Ghent was identified without a marital status. ${ }^{32}$ While there were 322 likely many widows in this group, there were undoubtedly many unmarried 323 women as well. Ninety of these women were identified by male family mem- 324 bers, such as a father or brother, which suggests that they were not (yet) mar- 325 ried. After all, the egalitarian inheritance custom in Brussels made it possible 326 
for girls to own property, regardless of their marital status. Furthermore, some 327 of these women were probably married, but the clerks did not consider this information relevant for registration. The primary goal of the clerks was to identify the rightful owner of the property, not to record the possible guardianship of the women in question. Despite the lack of marital and social information on female rent payers, it is clear that not all female landowners in Brussels were widows.

Identification patterns for women mirror the lack of information about the marital status of women. The clerks identified 59 per cent of the 967 female landowners without any reference to a man. These women were described solely by their first and last names (40 per cent), with titles indicating a higher social status (18 per cent), or with an occupational or religious affiliation (1 per cent). Another 40 per cent was identified by male family members or (former) husbands, and the final 1 per cent by female family members. This pattern provides additional support for the conclusion that the censier clerks were not particularly concerned about linking women to male family members, a notable exception to the pattern in other European regions, where the identification through male relatives was the norm. ${ }^{33}$ It is possible that clerks named these additional people to indicate the origin of the property, such as including a former husband, for example, to signal that the woman was dealing with property coming from the marital estate. The identification pattern strongly supports the conclusions of Ellen Kittell and Shennan Hutton for cities in Flanders. It was far from unusual for clerks in the medieval Low Countries to omit familial associations or marital status for women, which Kittell and Hutton consider as evidence of the relatively extensive economic opportunities for women in this region. ${ }^{34}$

Although the group of female real estate owners was diverse in terms of their marital status, there were far fewer of them than male owners. Women comprised only 13.8 per cent of the cens payers, either alone or in a group. For a city where egalitarian inheritance was the rule, this share seems surprisingly limited, but the absence of comparable studies of urban property ownership makes assessing the proportion difficult. For the high Middle Ages, one point of comparison is available. Stephen Bensch found that women owned on average 16 per cent of the land in Barcelona between 1100 and 1290, which resembles the share of women in late medieval Brussels. ${ }^{35}$ In this city, the inheritance rights of women resembled those of the Low Countries: a system of equal inheritance based on Visigothic law prevailed, and dowered daughters remained entitled to their share of the inheritance. Despite these provisions, families increasingly used testaments and legal loopholes to divert real property to male heirs, causing women to control less real estate than men. ${ }^{36}$

For the later Middle Ages, comparable studies are equally rare. ${ }^{37}$ Although 
used censiers to determine the percentage of women among urban property 369 owners, both dealt with the mid-fourteenth century, an exceptional period, 370 which does not provide an adequate basis for comparison. In both studies, 371 women paid at least 30 per cent of the cens, but a direct comparison of 372 these cities with Brussels would be misleading. Apart from the lack of detail 373 on these female landowners (for example, there is no quantitative analysis of 374 marital status), women in these southern European cities had less favourable 375 inheritance rights than their counterparts in the Low Countries. In most south- 376 ern European cities, families had greater latitude in distributing their property. 377 Even in regions were a system of equal inheritance between sons and daugh- 378 ters prevailed in theory, such as Marseilles, it was rarely practised due to the 379 many legal instruments to alter this. ${ }^{38}$ The most prominent instrument, next to 380 the testament, was the dowry system: receiving a dowry upon marriage gener- 381 ally excluded girls from a further share in the patrimony. ${ }^{39}$ Daughters' dowries 382 were moreover increasingly paid in cash from the thirteenth century onwards, 383 whereas real property was directed to sons. ${ }^{40}$

The large share of female landowners in fourteenth-century Avignon and 385 Marseilles was therefore caused by the devastating consequences of the 386 Black Death in the region, which gave women a better chance to acquire 387 land for a short period of time. These conditions probably did not occur in 388 the late medieval Low Countries. Historians have argued that the first and 389 most severe wave of the Black Death, in 1347-1350, had marginal impact 390 on the Low Countries, and later waves did not cause the same demographic 391 and economic disruption as occurred in southern Europe or England. ${ }^{41}$ In 392 Brussels, plague mortality seems to have been minimal in the fourteenth cen- 393 tury; there is no trace of an epidemic in the fourteenth-century sources, which 394 even remark on high population density in the 1380s. The city seems to have 395 been spared severe waves of plague until the 1400s. ${ }^{42} 396$

In contrast to the lack of studies of urban property ownership, there are more 397 of female landowners in rural regions, although as yet not of late medieval 398 Low Countries. Studies of rural landownership in other European regions 399 often contain the percentage of women owners. On English manors, for 400 example, women held approximately 20 per cent of the land before the 401 Black Death, but that number declined to 10 per cent or less in the sixteenth 402 century. There are substantial differences between this region and Brussels. 403 Not only were the property structures in this rural region very distinct, but 404 the inheritance customs also differed. In the English countryside, inheritance 405 customs favoured men. Moreover, English female landowners were almost 406 always widows. ${ }^{43}$ Nevertheless, it is noteworthy that the proportion of female 407 landowners in Brussels, an urban region with egalitarian inheritance customs, 408 hardly differed from the percentage of women landowners in rural England 409 where women had limited inheritance rights. 
Since comparing Brussels to other regions does not explain why there was 411 such a small percentage of female landowners, the reasons must be sought in the sources and Brussels property structures. A primary consideration is whether the registers always recorded the rightful owner(s) of the property. After all, the censiers were administrative documents and clerks might have preferred to write down the name of the (male) head of a household as the payer, rather than the (female) legal owner of the property involved. The marital property laws of Brussels stipulated that a married woman remained the legal owner of her property, but she could only act under the guardianship of her husband. For this reason, it is possible that the clerks registered only the woman's husband as the payer on her property, and therefore failed to mention a substantial group of female property owners in the registers. However, since 20 per cent of the women named were married, omission of married women was certainly not the rule and cannot sufficiently explain the small number of female landowners. Moreover, although censiers were used for administration, they also had a legal function: if the legal contract was missing, a censier could be used to prove the right to the cens. Therefore, it was important to identify the rightful owner, and the clerks based their listings in the censiers on the legal contracts. ${ }^{44}$ To the extent it was possible, cross-checking verified that clerks did not systematically omit the name of a married woman if she was mentioned as a party in the contract. ${ }^{45}$ When the cens was paid on the couple's communal property or on the husband's personal property, the name of the woman was probably not included.

Therefore, the main explanation for the small proportion of women probably involves the methods of acquiring real estate: inheritance or sale. First, the gendered distribution of the property in the censiers suggests that daughters received less real property than sons. Within that regard, it is striking that the share of female landowners in late medieval Brussels was similar to women's share in high medieval Barcelona, where families directed real property to sons despite egalitarian inheritance customs. Historians have argued that families in the late medieval Low Countries gradually adopted more patrilineal strategies towards property. In Douai, as Martha Howell found, they did so by limiting women's rights to manage property in marriage contracts. ${ }^{46}$ Although not used in Douai, another strategy might have been to direct real property to sons, as has been found for other European regions and higher officials in Flanders. ${ }^{47}$ There is, however, no systematic research on family distribution of property in actual practice in the Low Countries. Despite the egalitarian inheritance system of Brussels, families could direct their real property to male heirs by two methods, compensating female heirs with movable property and writing testaments that altered the customary system of inheritance. ${ }^{48}$ 
The results also suggest that women sold real estate more often than buying 453 it when they were active in the property market. More women than men might 454 have sold real estate, either out of necessity, or because they preferred freeing 455 up capital for investment, for example in annuities, in order to secure a steady 456 income. There have been few studies of the financial strategies of urban medi- 457 eval women, but many scholars have pointed towards women's preference for 458 life annuities as low-risk investments. ${ }^{49}$ Many women might also have been 459 co-owners of property along with other heirs, which offered an inducement 460 to sell their portion. As buyers, men probably far outnumbered women in 461 the Brussels property market. Although they pay little attention to women, 462 studies of property markets in Low Countries cities suggest that there were 463 few women among real estate buyers. ${ }^{50}$ Although these two factors are tenta- 464 tive, they could explain why the percentage of female landowners in Brussels, 465 a city with egalitarian inheritance, was similar to the percentage of women 466 landowners in rural England, where inheritance customs were less favourable 467 to women.

6. CHANGES IN THE PROPORTION OF WOMEN AMONG LANDOWNERS IN LATE

Although they were a minority, there were women among the landowners of late medieval Brussels, and that pattern of female landownership underwent significant changes during the fourteenth and fifteenth centuries. In analysing these changes, the first consideration must be the changes in censiers of the same institution, as the methodology requires. There are successive registers for eight of the twelve institutions, and seven of these have registers from both the fourteenth and fifteenth centuries. Figure 2 displays the proportion of women landowners in the earliest and latest surveys from each of the seven institutions.

The general evolution in the cens circles of the majority of these institutions (five out of seven) is a clear decline from the fourteenth to fifteenth centuries in the number of women among the payers. Depending on the institution, the decline fluctuated between five and eight percentage points. However, in the registers of two smaller institutions, there is a different pattern. In the registers of Ter Kisten, a foundation of the beguinage, and St John's Hospital, the proportion of women remained relatively stable, probably because both institutions were somewhat exceptional. The percentage of women cens payers for St John's Hospital was exceptionally high. In the 1356 register, women comprised at least 30 per cent of its cens payers, and in the 1409 register, this number increased to 31 per cent, both 10 to 20 percentage points more than the average for the other institutions. ${ }^{51}$ Only one register, for the Coudenberg poor table, had a remotely similar percentage of female landowners. The 


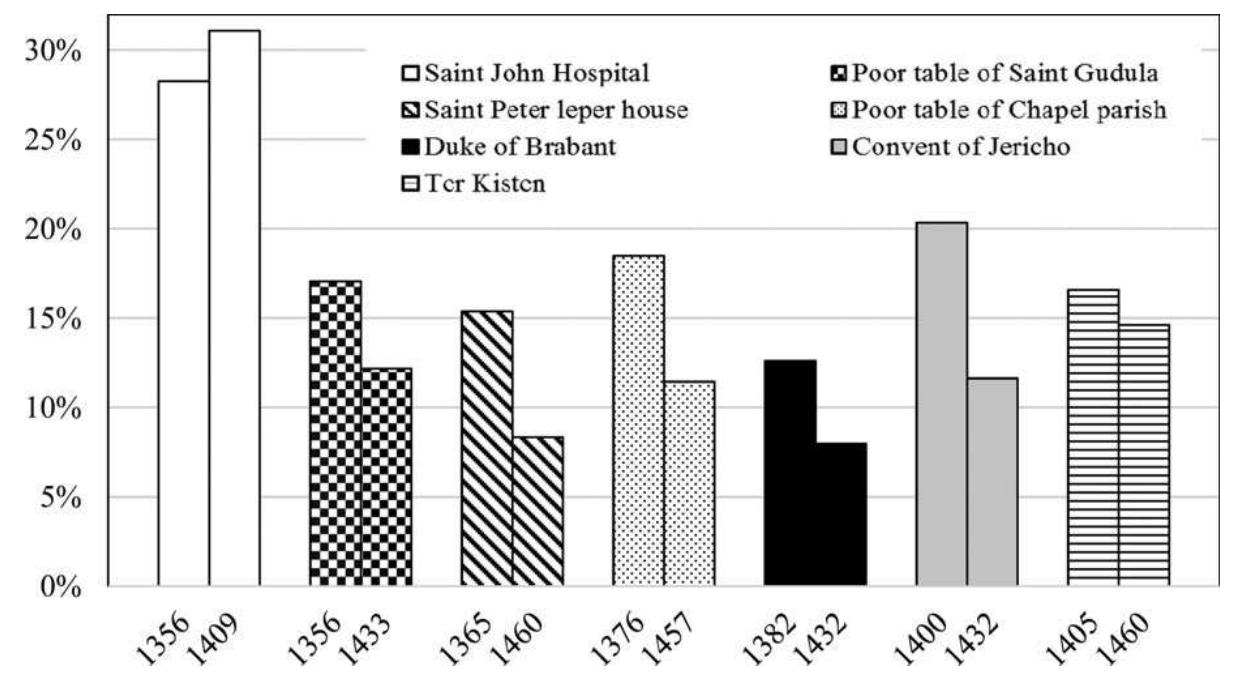

Figure 2. Percentage of cens paid by women (both independently and with others) in censiers of the same institution in the fourteenth and fifteenth centuries. Source: See Appendix Table 1.

payers in the Coudenberg register, which will be discussed further below, were almost all from the city's elite. It is likely that elite status characterised many of the female cens payers in the registers of St John's hospital. Some studies point to a link between the hospital and (female) members of the urban elite, ${ }^{52}$ although more research on this institution is needed. The registers of Ter Kisten contained 17 per cent women in 1405, a number that declined to 15 per cent in 1460 . This foundation was governed by women and aimed towards women, as it supported poor beguines in Brussels. These features may account for the more consistent percentages of women in the cens circle of this institution.

Despite these two exceptions, the clear pattern is that the number of women registered as owners of landed property encumbered with a cens declined over the late medieval period. Because Brussels was not significantly disrupted by the Black Death in the fourteenth century, it is unlikely that this was the correction for a temporary spike in the percentage of women landowners after the epidemic, as argued for Marseilles and Avignon. Instead, during the late medieval period, women's importance as landowners in late medieval Brussels declined. The mechanisms behind this decline are difficult to pinpoint from the censiers: were women inheriting less property than men? Were they selling more properties than men, either out of necessity, or because they preferred to free up the capital and potentially invest it? The next paragraph looks more closely at the potential causes behind the decline of female landownership. The fact that this decline did not prevail in all the registers indicates that it was not universal, and more variables need to be considered. 
Juxtaposing data from the censiers with economic history and social topography of Brussels reveals more about the decline in female ownership. As treatment of the entire period is not possible within the scope of this article, the analysis focuses a central 'episode' in the decline, the period between 1370 and 1440, in two distinct neighbourhoods. These two were selected because they were well documented in the surviving censiers, often for the same institutions. In addition, the two neighbourhoods had distinctly different social profiles. The neighbourhood of the Chapel, a suburban district in the south of the city (IV on Figure 1), was dominated by artisans and workshops. The neighbourhood of the Coudenberg was located in the city centre (III on Figure 1). Lying around the duke's castle, it was most prosperous district of late medieval Brussels.

After extensive tumult from economic crises, political and social protests and uprisings in the mid-fourteenth century, Brussels experienced relative economic prosperity after 1370 . Several censiers dated around 1380 show that women made up between 15 and 19 per cent of the cens payers across the city's neighbourhoods. After 1390, this number started to decline. The decline was mostly concentrated in the areas between the first and the second city walls, the city's suburbs. Although little is known about the social topography of Brussels specifically, studies of other medieval cities in the region have shown that residents in the city centre were more often members of the urban elite and were more prosperous than people living on the city's periphery, who were more likely to be from the middle and lower classes. ${ }^{53}$

The timing of this decline beginning in the 1390s coincides with renewed 541 economic crisis. Many elements of this crisis were not restricted to Brussels, but were tangible throughout the Duchy of Brabant and beyond. ${ }^{54}$ The first signs of a looming crisis in Brussels's cloth trade were already starting to appear in the relatively prosperous period of the 1370 s and 1380 s. In the 1390 s, cloth production and sales fell, and by the end of the century, the crisis was in full swing. As cloth was the most important sector in the urban economy of Brussels, the effects on the city were severe. Enhanced by extremely enon due to a chronic shortage of silver during this period affected purchasing 552 power and caused social unrest. ${ }^{55}$ In 1405 , the revenue from urban excise taxes 554 was 22 per cent lower than in 1372. Economic difficulties impacted on the 555 city's inhabitants until the 1430s. There were additional signs of the general 556 impoverishment of the city, such as increasing defaults in the property and 557 credit markets, coin devaluations, increasing grain prices (with very high 558 
prices around 1415-1417 and 1430-1431), uprisings (1416 and 1421), and a 559 slow depopulation of the city. ${ }^{56}$ In 1436, the city government issued a number 560 of measures to improve the economy, which included protecting citizen's 561 properties from confiscation when they failed to pay the expenses, such as 562 cens, on their properties. The introduction to the charter speaks volumes; it 563 was done because 'the city's economy is sick, which has been the case for a long time, and it is becoming more and more weak ... to the extent that the number of people is declining, the houses are falling into decay, and the city is largely deteriorating'. ${ }^{57}$

In no neighbourhood was this decline more visible and drastic than in the parish of the Chapel (Kapelleparochie), located in the south of the city around the main entry road, the Hoogstraat. Whereas the percentage of female landowners fell in other suburban areas with 3 to 7 percentage points, it fell with 10 percentage points in the Chapel parish. This artisanal and industrial neighbourhood would have suffered especially severely from economic crisis because it was heavily dependent on the textile industry. ${ }^{58}$

Figure 3 illustrates the change in the percentage of women among landowners in the Chapel across succeeding surveys dating between 1382 and 1433. ${ }^{59}$ The surveys stem from the two institutions that levied the largest number of cens in the city: the duke of Brabant (surveys of 1382, 1399 and 1432) and the St Gudula poor table (surveys of 1390 and 1433).

After the 1390s the proportion of women among the landowners in the parish of the Chapel shrank noticeably. Since this decline is visible in the surveys of both institutions, it was not a reflection of institutional or administrative changes within a cens circle. Whereas women paid roughly 15 per cent of the cens in 1382 and 1390, their proportion declined to 5 per cent by 1399 and even less by 1432 . The number does not seem to have improved significantly until the 1460s, although the lack of censiers of these institutions for the 1440 s and 1450 s makes the number more difficult to evaluate.

The ducal registers of 1382 and 1399 shed additional light on this rapid and sustained decline of women among landowners in the parish. Six of the twelve women who were cens payers in 1399, were also registered as a payer in 1382 . Five of these six belonged to wealthy Brussels families. ${ }^{60}$ While their high social status provided them with the resources to retain their property in trying economic conditions, most ordinary female property owners in 1382 did not have this advantage. Belonging to the city's elite seems to have been less important for male property owners, as only the names of 5 of the 179 male cens payers in 1399 were accompanied by a title. The association of a high social status with female property owners is again apparent in 1432, when only 4 of the 145 cens payers were women, two of whom came from families associated with Brussels elite. ${ }^{61}$ In the register of 1433, only 2 of 52 cens were paid by women: Zuete Ghijsels, whose social standing remains unknown, and 


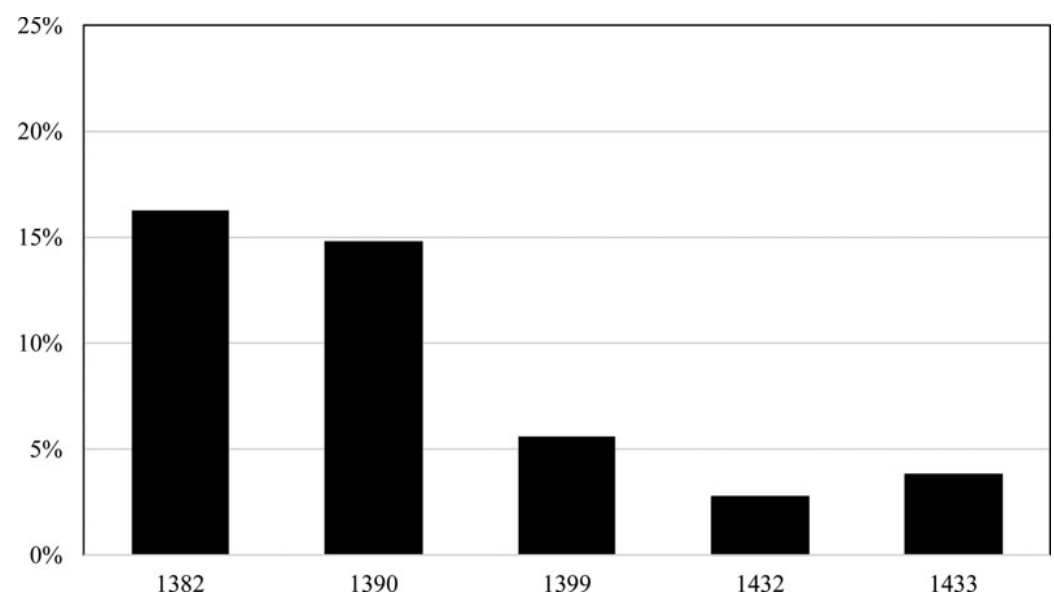

FIGURE 3. The percentage of cens paid by women (both independently and with others) in the parish of the Chapel in the registers of the Duke of Brabant $(1382,1399,1432)$ and the registers of the poor table of St Gudula (1390, 1433). Source: See Appendix Table 1.

the wife of Jacob int Scildeke, who was identified as a female brewer (brie- 601 dersse). The fact that she was identified by her occupation is extraordinary 602 in itself. She seems to have inherited the property from her father. ${ }^{62}$

In a relatively brief period, the last decade of the fourteenth century, the 604 gendered distribution of real property in the Chapel parish changed profoundly. Since the censiers do not enable a study of the actual property market or inheritance patterns, the exact causes cannot be definitively identified. Nevertheless, the timing and geographical concentration of the decline point towards certain mechanisms. The rapid decline of women among cens payers during a period of crisis suggest that this was not caused by female investment strategies, that is, women preferring to sell their property to free up capital for investment purposes. After all, this was a very unfavourable time for selling real estate or investing in capital: the difficult economic conditions probably led to low real estate prices and a low demand for capital. ${ }^{63}$ Instead, it is more likely that harsh economic circumstances forced more women than men to sell their properties out of necessity, ${ }^{64}$ and that in the meantime, few women received real property through inheritance. Only women with high social status were able to retain their properties.

During the early fifteenth century, the Chapel parish continued to suffer; 619 sources describe the impoverishment and depopulation of the quarter. 620 During these thirty years, women's share among real estate owners in the 621 neighbourhood continued to be minimal, as in 1,433 women paid less than 622 5 per cent of the cens. Several factors may have been at work preventing 623 women from acquiring real property. Inheritance patterns may have shifted, 624 as middling families tried to keep their patrimonies intact during economic 625 hardship by directing their real property to male heirs while compensating 626 
women with movable goods. Women might have been less inclined than men 627 to buy real estate and more likely to have to sell their properties out of financial 628 necessity.

The parish of the Coudenberg presents a completely different picture. While the percentage of women among landowners in all quarters of Brussels declined between 1390 and 1440, and the suburbs were particularly affected, the Coudenberg neighbourhood was the one exception. Located around the castle of the duke of Brabant, this was a wealthy neighbourhood. After the 1420 s more and more of its residents were members of the Brussels elite or the ducal entourage and professionals working in the ducal court or administration. 65

Figure 4 shows the percentage of cens paid by women, based on the same censiers that were used for the analysis of the Chapel parish, those of the duke of Brabant (surveys of 1382, 1399 and 1432) and of the St Gudula poor table (surveys of 1390 and 1433). They are supplemented by a smaller register from the poor table of Coudenberg parish (1430), which contained property only in this part of the city.

Landownership of women in the elite Coudenberg quarter shows an entirely different evolutionary pattern from that of women in the Chapel and the rest of Brussels. There was no decline in the proportion of women among landowners at all, as the percentage actually grew from 16 to 17 per cent in 1382 to 19 to 25 per cent in the fifteenth century. The profile of female cens payers corresponds to what is known about the inhabitants of this neighbourhood. Some of them were linked to the ducal court through family members, such as the remarried widow Lijsbet van Coeborchts, who was the sister-in-law of the renowned chronicle writer Edmond van Dynther. Others came from elite families, like the widow of city secretary Johannes Daneels. Clerks identified several women with titles conveying their social status, and others with nicknames that made reference to their wealth (such as Margriete van Huesdeyn, called metten Dyamanten or 'with the diamonds'). ${ }^{6}$ Some women owned extensive properties. Others also owned businesses, such as the widow Katlene Petits, who paid a cens for her 'stalls, bedrooms and haylofts behind her tavern' ${ }^{67}$ Contracts in the poor table's archives show that Katlene had administered this property from 1410.

Most of the cens payers from the Coudenberg came from higher social groups than those in the Chapel. The fact that the proportion of women among real estate owners remained steady, and even increased slightly indicates that these women had sufficient reserves to keep their properties, and even invest in more property, despite the harsh economic climate, and families were able to continue providing their female members with valuable real property.

Beginning in the late fourteenth century, during a prolonged time of eco- 


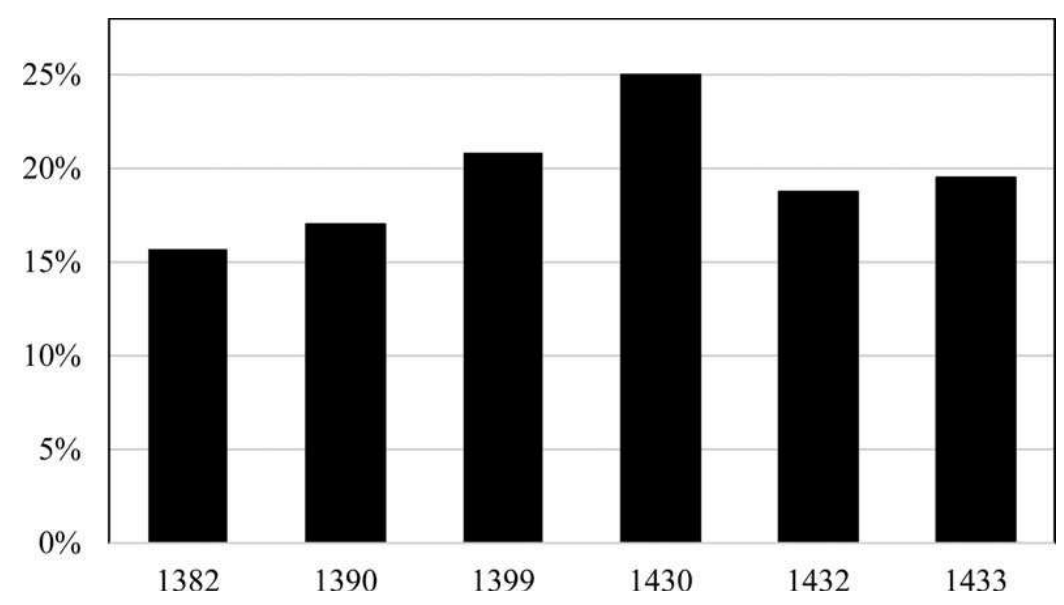

FIGURE 4. The percentage of cens paid by women (both independently and with others) in the parish of Coudenberg in the registers of the Duke of Brabant (1382, 1399 and 1432), the registers of the poor table of St Gudula (1390 and 1433) and the register of the poor table of Coudenberg (1430). Source: See Appendix Table 1.

male, and the pool of female landowners narrowed to women of the urban 669 elites. The censiers make it clear that the economic crisis had a strong gen- 670 dered impact on ownership patterns. Only women from the highest social 671 groups of the city withstood the general decline in female landownership. 672 Without a doubt, the unfavourable economic climate had a profound impact 673 upon the ability of people from the lower and middle social groups to obtain 674 and retain real estate. Other studies of medieval property markets have shown 675 that periods of economic decline were marked by social polarisation among 676 property owners; with fewer reserves, less wealthy people were the first to 677 fall short of funds, and so lose the chance to buy or keep real property. ${ }^{68} 678$ No study has touched upon the gendered dimension of this process, however. 679 Certainly men as well as women from the middle classes were affected by the 680 crisis, but the landownership of women declined more sharply than the land- 681 ownership of men in the non-elite groups of the city. Only on the Coudenberg, 682 by far the wealthiest neighbourhood of late medieval Brussels, did this 683 sharpened gender inequality in real property ownership not occur.

Although men paid the large majority of the cens on real property in late medi- 686 eval Brussels, women on average were responsible for the payment of 14 per 687 cent. In some neighbourhoods of the city, this number rose to 25 per cent. 688 Explanations for the relatively limited proportion of women are most likely 689 to be found in inheritance patterns and gendered participation in property mar- 690 kets, for which more research is needed. Nonetheless, all of these women 691 
landowners possessed important resources, and as such, were in a favourable position to participate in the urban economy. This group of female landowners was much more varied in terms of marital status than is often assumed in the historiography. Women identified as widows did not constitute the majority of the women in the sources, as married women and women with no recorded marital status were numerous.

Between 1356 and 1460, women's property ownership was far from stable, as there was a decline in the percentage of women among landowners in late medieval Brussels. The reasons for this decline of female landownership cannot be definitively identified from the censiers, but the results tentatively indicate it was caused by shifts in inheritance patterns or female impoverishment. This suggests that women in Brussels lost access to an important resource for their economic activity, a conclusion that adds support to the argument that economic opportunities declined for women during the late Middle Ages, as has been found by Martha Howell, Shennan Hutton and others. However, the results emphasise that these changes played out differently for women of different social groups. Indeed, the decline in women's landownership was neither linear nor unequivocal, since the decrease accelerated during economic crises and was closely connected to the social status of women. Economic crises affected both sexes, but unevenly; in the resulting social redistribution of property, gender was a significant factor.

While long-term comparison of censiers has offered new insights into the changes in women's economic position from the perspective of landownership, it has also inevitably left many questions unanswered, partly due to a lack of comparable studies. In order to understand the precise mechanisms behind the decline of women's landownership among non-elite groups and the degree to which this case study of the Low Countries compares to other European cities, more research is required. Very little remains known about medieval women's wealth management and their investment strategies on capital and property markets. Case studies of a diverse range of comparable cities are needed to assess how local factors, such as variations in legal and economic structures, impacted on women's access to wealth and economic opportunities. This study recommends that economic activities besides labour should be included in the analysis of the fundamental changes in women's economic opportunities during the late Middle Ages. The findings also emphasise the need to include class as an explicit category of analysis. Social differences between women are not centrally considered in current research on medieval urban women, in part because of the historiographical focus on labour. Because women of different social groups had differing access to property, and therefore to economic opportunities, it is essential to recognise that late medieval changes affected them in divergent ways. Future research on (urban) women's control and management of wealth would therefore benefit 
from a more explicit analysis of the interaction among social status, marital 734 status and gender.

Andrea Bardyn is a Fellow of the Research Foundation, Flanders. The author would like to thank 737 Jelle Haemers, Shennan Hutton, Bram Vannieuwenhuyze, Kaat Cappelle, and the anonymous 738 reviewers for their helpful comments on earlier drafts of this article. For a more extensive discus- 739 sion of the methodology and the first case on the parish of the Chapel, see Andrea Bardyn, 740 'Vermogende vrouwen: Het vastgoedbezit van vrouwen in laatmiddeleeuws Brussel op basis 741 van cijnsregisters (1356-1460)', Stadsgeschiedenis 9, 1 (2014), 1-24.

\section{Appendix}

Overview of censiers with the total number of cens and the percentage of cens paid by women (independently and with others) (1356-1460)

\begin{tabular}{|c|c|c|c|c|}
\hline Year & Institution & $\begin{array}{l}\text { Number of } \\
\text { cens }\end{array}$ & $\begin{array}{l}\text { Cens paid by } \\
\text { women (\%) }\end{array}$ & Archival reference ${ }^{a}$ \\
\hline 1356 & Poor table of St Gudula & 299 & 17.06 & $\mathrm{AOB}, \mathrm{BF}$, no. 211 \\
\hline 1356 & St John hospital & 138 & 28.26 & AOB, SJ, no. 17 \\
\hline 1365 & St Peter leper house & 39 & 15.38 & AOB, SP, no. 12 \\
\hline 1369 & Poor table of St Gudula & 444 & 15.99 & AOB, BF, no. 212 \\
\hline 1370 & Hospital of beguinage & 156 & 10.90 & AOB, HP, no. 312 \\
\hline 1390 & Poor table of St Gudula & 397 & 17.63 & AOB, BF, no. 213 \\
\hline 1376 & $\begin{array}{l}\text { Poor table of the } \\
\text { Chapel }\end{array}$ & 395 & 18.48 & AOB, BF, no. 1376 \\
\hline 1382 & Duke of Brabant & 1,157 & 12.62 & ARA, RK, no. 44286 \\
\hline 1387 & St Peter leper house & 43 & 16.28 & AOB, SP, no. 14 \\
\hline 1393 & $\begin{array}{l}\text { Poor table of St } \\
\text { Gaugericus }\end{array}$ & 209 & 15.79 & AOB, BF, no. 681 \\
\hline 1399 & Duke of Brabant & 1,264 & 9.26 & ARA, RK, no. 44288 \\
\hline 1400 & Convent of Jericho & 59 & 20.34 & RAAnd, KAB, no. 12935 \\
\hline 1405 & Foundation ter Kisten & 193 & 16.58 & AOB, BF, no. 1544 \\
\hline 1406 & St Jacob hospital & 56 & 19.64 & $\begin{array}{l}\text { AOB, Sint-Jacobsgasthuis, } \\
\text { no. } 17\end{array}$ \\
\hline 1409 & St John hospital & 222 & 31.08 & AOB, SJ, no. 18 \\
\hline 1414 & Hospital of beguinage & 82 & 18.29 & AOB, HP, no. 287 \\
\hline 1420 & Convent of Jericho & 87 & 13.79 & RAAnd, KAB, no. 12934 \\
\hline 1430 & $\begin{array}{l}\text { Poor table of } \\
\text { Coudenberg }\end{array}$ & 56 & 25.00 & RAAnd, KAB, no. 6926 \\
\hline 1432 & Duke of Brabant & 815 & 7.98 & ARA, RK, no. 44830 \\
\hline 1432 & Convent of Jericho & 86 & 11.63 & RAAnd, KAB, no. 12936 \\
\hline 1433 & Poor table of St Gudula & 468 & 12.18 & $\mathrm{AOB}, \mathrm{BF}$, no. 216 \\
\hline 1436 & Foundation ter Kisten & 138 & 13.04 & AOB, BF, no. 1469 \\
\hline 1444 & Jan van Aa & 81 & 16.05 & Gonthier \\
\hline
\end{tabular}


Appendix (cont.)

\begin{tabular}{|c|c|c|c|c|}
\hline Year & Institution & $\begin{array}{c}\text { Number of } \\
\text { cens }\end{array}$ & $\begin{array}{c}\text { Cens paid by } \\
\text { women (\%) }\end{array}$ & Archival reference ${ }^{a}$ \\
\hline 1456 & Foundation ter Kisten & 122 & 12.30 & AOB, BF, no. 1472 \\
\hline 1457 & $\begin{array}{l}\text { Poor table of the } \\
\text { Chapel }\end{array}$ & 236 & 11.44 & AOB, BF, no. 885 \\
\hline 1460 & Foundation ter Kisten & 130 & 14.62 & AOB, BF, no. 1472 \\
\hline \multirow[t]{2}{*}{1460} & St Peter leper house & 48 & 8.33 & AOB, SP, no. 17 \\
\hline & Total & 7,420 & 13.8 & \\
\hline
\end{tabular}

${ }^{a}$ Abbreviations used: AOB (OCMW Archive Brussels) with fonds BF (Bienfaissance), HP (Hopïtaux), SJ (Sint-Jansgasthuis), SP (Sint-Pietersleprozerij); ARA (State archives of Belgium) with fond RK (Rekenkamer); RAand (State archives of Belgium - Anderlecht) with fond KAB (Kerkelijk archief Brabant); Gonthier (André Gonthier, 'La fortune d'un bourgeois de Bruxelles au XVe siècleL le livre censier de Jean van Aa', Annales de la Société Royale d'Archéologie de Bruxelles 48 (1948-1955), 105-43).

\section{ENDNOTES}

1 Sarah Rees Jones, 'Public and private space and gender in medieval Europe', in Judith M. Bennet and Ruth Mazo Karras eds., The Oxford handbook of women and gender in medieval Europe (Oxford, 2013), 250.

2 A good overview of recent studies is provided in the introduction of Kate Kelsey Staples, 751 Daughters of London: inheriting opportunity in the late Middle Ages (Leiden, 2011), 1-13.

3 Some notable exceptions include Kathryn Reyerson, 'Women in business in medieval Montpellier', in Barbara Hanawalt ed., Women and work in preindustrial Europe (Bloomington, 1986), 117-44: Shennan Hutton, Women and economic activities in late medieval Ghent (New York, 2011).

4 For a recent study that succeeded in overcoming these obstacles through an original source approach, see Margaret Yates, 'Married women and their landholdings: the evidence from feet of fines, 1310-1509', Continuity and Change 28, 2 (2013), 163-85.

5 David Nicholas, for example, considered censiers to be of little value for his research on women in fourteenth-century Ghent, as they 'tell us little of the role of women [because] women are statistically insignificant as payers of a [census]'. See David Nicholas, The domestic life of a medieval city: women, children and the family in fourteenth-century Ghent (Lincoln, 1985), 70.

6 To my knowledge, three studies do offer quantitative information on the gender distribution of 765 real property ownership in late medieval cities, but only for one moment in time. Margret 766 Wensky, Die Stellung der Frau in der Stadtkölnischen Wirtschaft im Spätmittelalter (Graz, 767 1980), 312-15; Daniel Lord Smail, 'Démanteler le patrimoine: les femmes et les biens dans 768 la Marseille médievale', Annales: Histoire, Sciences Sociales 52, 2 (1997), 343-68; Joëlle 769 Rollo-Koster, 'The boundaries of affection: women and property in late medieval Avignon', 770 in Jutta Sperling and Shona Kelly Wray eds., Across the religious divide: women, property, 771 and law in the wider Mediterranean (ca. 1300-1800) (New York, 2010), 38-51. For the 772 high Middle Ages, two studies did quantify changes in women's landownership. David 773 Herlihy charted evolutions in female landownership in the whole of continental Europe 774 
between 700 and 1200 based on samples of charters. See David Herlihy, 'Land, family and 775 women in continental Europe, 701-1200', Traditio 18 (1962), 89-120. In his study of the 776 growth of Barcelona and its ruling classes, Stephen Bensch included a discussion of the 777 share of female property holders in Barcelona between 1100 and 1290. See Stephen 778 Bensch, Barcelona and its rulers, 1096-1291 (Cambridge 1995), 258.

7 For north-western Europe, see among others, Wensky, Die Stellung; Martha C. Howell, Women, production, and patriarchy in late medieval cities (Chicago, 1986); Marjorie McIntosh, Working women in English society, 1300-1620 (Cambridge, 2005); Barbara Hanawalt, The wealth of wives: women, law, and economy in late medieval London (New York, 2007); Hutton, Women; Peter Stabel, 'Working women and guildsmen in the Flemish textile industries (13th and 14th century)' (forthcoming).

8 Martha C. Howell, The marriage exchange: property, social place, and gender in cities of the Low Countries, 1300-1550 (Chicago, 1998).

9 Caroline M. Barron, 'The "golden age" of women in medieval London', Reading Medieval 788 Studies 15 (1989), 35-58; Jeremy P. Goldberg, Women, work, and life cycle in a medieval 789 economy (Oxford, 1992). $\quad 790$

10 Tine De Moor and Jan Luiten van Zanden, 'Girl power: the European marriage pattern and 791 labour markets in the North Sea region in the late medieval and early modern period', 792 Economic History Review 63, 1 (2010), 1-33, here 16. 793

11 For the Low Countries, see, for example, Marc Boone, Machteld Dumon and Birgit Reusens, 794 Immobiliënmarkt, fiscaliteit en sociale ongelijkheid te Gent 1483-1503 (Kortrijk, 1981). 795

12 Many historians have pointed to the relationship between landownership and creditworthiness 796 in the Low Countries. See, for example, Jaco Zuijderduijn, 'Assessing a medieval capital mar- 797 ket: the capacity of the market for renten in Edam and De Zeevang (1462-1563)', Jaarboek 798 voor middeleeuwse geschiedenis 11, 1 (2008), 138-9, 148, and the cited literature there. 799

13 Jaco Zuijderduijn, Medieval capital markets: markets for renten, state formation and private 800 investment in Holland (1300-1550) (Leiden, 2009), 10-11; Philippe Godding, Le droit 801 privé dans les Pays-Bas méridionaux du 12e au 18e siècle (Brussels, 1987), 480-5. 802

14 Joëlle Rollo-Koster, 'The boundaries of affection', 47-8. 803

15 Claire Dickstein-Bernard, 'Bruxelles: résidence princière (1375-1500)', in Mina Martens ed., 804 Histoire de Bruxelles (Toulouse, 1976), 139-65. 805

16 Eduard Maurits Meijers, Het West-Brabantsche erfrecht (Haarlem, 1929), 110-11. 806

Q4 17 See also p. 13. Martha C. Howell, 'The social logic of the marital household in cities of the late 807 medieval Low Countries', in Myriam Carlier and Tim Soens eds., The household in late medi- 808 eval cities: Italy and northwestern Europe compared (Leuven, 2001), 189-91. 809

18 Godding, Le droit privé. $\quad 810$

19 Eric Bousmar, 'Neither equality nor radical oppression: the elasticity of women's roles in the 811 late medieval Low Countries', in Ellen Kittell and Mary Suydam eds., The texture of society: 812 medieval women in the southern Low Countries (Basingstoke, 2004), 109-27. 813

20 Ellen Kittell, 'Guardianship over women in medieval Flanders: a reappraisal', Journal of 814 Social History 31, 4 (1998), 897-930; Hutton, Women, 36-58. 815

21 Robert Fossier, Polyptiques et censiers (Turnhout, 1978), 67.

22 Although they were not completely identical, a cens or cijns is best translated as 'burgage rent' 817 or 'socage rent' as existed in urban England. To compare, see Vanessa Harding, 'Space, 818 property, and propriety in urban England', Journal of Interdisciplinary History 32, 4819 (2002), 553-4.

23 Smail, 'Démanteler le patrimoine'; Rollo-Koster, 'Boundaries'. Joëlle Rolle-Koster did combine gender analysis of a censier with social topography, but from the perspective of the cens collector. She reconstructed the lordship of a female convent in Avignon over properties throughout the city. See Joëlle Rollo-Koster, 'From prostitutes to virgin brides of Christ: the 
Avignonese Repenties in the late Middle Ages', Journal of Medieval and Early Modern Studies 32, 1 (2002), 125-6.

24 This overview is based on Philippe Godding, Le droit foncier à Bruxelles au Moyen Age (Brussels, 1960).

25 All archival references are given in the overview table (see Appendix).

26 A complete overview and discussion of all censiers drawn up by institutions from Brussels can be found in Bram Vannieuwenhuyze, Laatmiddeleeuwse Brusselse cijnsregisters (12de-15de eeuw): een schitterende bron voor de historische topografie van Brussel en haar omgeving (Brussels, 2014).

27 An example: 'Item, my lady Margriete, former wife of Henrix Sloesen, yearly and hereditary xxxix s. x d. to be paid at Christmas, for a plot in the Steenstraat next to lord Diederex Loesen' (Free translation from: 'Item joncfrouwe Margriete, Henrix Sloesen wijf was, xxxix s. $x$ d. siaers erfleken te Kerssavont op een hofstat gheleghen in de Steenstrate bi tser Diederex Loesen') (OCMW Archive Brussels, fonds Hôpitaux, no. 312, fo. 7r).

28 The cens paid by institutions such as the city of Brussels and religious or charitable institutions were not included in the analysis.

29 On methodological considerations for censiers, see Andrea Bardyn and Bram Vannieuwenhuyze, 'Inleiding', in Vannieuwenhuyze, Laatmiddeleeuwse Brusselse cijnsregisters, 9-33. payer was not written down, or a payer was described as 'the children/heirs of X'. (OCMW Archives Brussels, Bienfaissance, no. 883, fo. 4r).

33 Judith M. Bennett and Ruth Mazo Karras, 'Women, gender and medieval historians', in Bennet and Karras eds., The Oxford handbook of women and gender in medieval Europe, 9. Specifically for Avignon, see Joëlle Rollo-Koster, 'The women of papal Avignon: a new source: the Liber Divisionis of 1371', The Journal of Women's History 8, 1 (1996), 36-59, here 49.

34 Hutton, Women, 149; Ellen Kittel, 'The construction of women's social identity in medieval 853 Douai: evidence from identifying epithets', Journal of Medieval History 25, 3 (1999), 215-27. 854

35 He analysed this by counting the owners of adjacent properties in 4,000 land transfers (Bensch, Barcelona, 258). Linda McMillen found a higher percentage of female landowners in the middle of the thirteenth century, but this is based on a small number of transactions concerning only leased property by one monastery. Of the 137 leaseholders of urban property, 27 per cent were women. See Linda McMillin, 'The house on Sant Pere Street: four generations of women's land holding in thirteenth-century Barcelona', Medieval Encounters 12, 1 (2006), 62-73, here 72.

37 To my knowledge, the only studies that give the gendered distribution of property ownership (not market activity) in late medieval cities are those mentioned by Daniel Lord Smail and Joelle Rollo-Koster (which will be discussed further), and Margaret Wensky's study, giving a percentage of female property owners from a taxation source. However, the source only includes heads of households (and thus mostly only widows) above a certain wealth level. See Wensky, Die Stellung, 312-15.

38 Francine Michaud, Un signe des temps: accroissement des crises familiales autour du patrimoine à Marseille à la fin du XIIIe siècle (Toronto, 1994), 83.

39 The exclusion of dowered daughters was the rule in most regions in southern Europe. 871 Nevertheless, there was significant regional variation. In Barcelona, as mentioned earlier, dow- 872 ered daughters were not disinherited. This was also the case in Lisbon. See, for a comparative 
study, Jutta Sperling, 'Dowry or inheritance? Kinship, property, and women's agency in 874 Lisbon, Venice, Florence (1572)', Journal of Early Modern History 11, 3 (2007), 197-238. 875

40 Rebecca Lynn Winer, Women, wealth, and community in Perpignan, c. 1250-1300 (Aldershot, 876 2006), 256 and the literature cited in note 57; Dana Wessel Lightfoot, Women, dowries and 877 agency: marriage in fifteenth-century Valencia (Manchester, 2013), 122-36.

41 Bas Van Bavel, 'People and land: rural population developments and property structures in the Low Countries, c. 1300-c. 1600', Continuity and Change 17, 1 (2002), 10-15, and the studies cited there.

42 Claire Dickstein-Bernard, 'Une ville en expansion (1291-1374)', in Martens ed., Histoire de Bruxelles, 100; Georges Despy, 'La "grande peste noire de 1348" a-t-elle touché le Roman Pays de Brabant?', in Centenaire du Séminaire d'Histoire médiévale de l'Université Libre de Bruxelles, 1876-1976 (Brussels, ), 195-217; Chloé Deligne, Bruxelles et sa rivière: genèse d'un territoire urbain (12 ${ }^{e}-18$ e siècle) (Turnhout, 2003), 109-10.

43 For example, in Norfolk, all identifiable female landowners in the period 1500-1529 were widows: Jane Whittle, 'Inheritance, marriage, widowhood and remarriage: a comparative perspective on women and landholding in north-east Norfolk, 1440-1580', Continuity and Change 13, 1 (1998), 33-72.

44 Godding, Le droit privé, 182-3.

45 For example, the censier of the poor table of the parish of the Chapel from 1376 was compared to several corresponding contracts from a charter book of the institution.

46 Howell, The marriage exchange, 124-43.

47 Jan Dumolyn, 'Patriarchaal patrimonialisme: de vrouw als object in sociale transacties in het laatmiddeleeuwse Vlaanderen: familiestrategieën en genderposities', Verslagen van het Centrum voor genderstudies - Ugent 12, 1 (2003), 1-28.

48 Philippe Godding points to the possibility to use testaments to (partly) circumvent customary devolution, for example to preserve the unity of the patrimony by compensating other heirs. He underlines, however, that research on actual practice is necessary (Godding, Le droit privé, 381, 393-4). In Brussels, testators had wide latitude in formulating their wills, more than in many other cities in the Low Countries. See Philippe Godding, 'Dans quelle mesure pouvait-on disposer de ses biens par testament dans les anciens Pays-Bas méridionaux?', Tijdschrift voor Rechtsgeschiedenis 50, 3 (1982), 279-96.

49 See the extensive overview of women's participation in financial markets in William C. Jordan, Women and credit in pre-industrial and developing societies (Philadelphia, 1993), 17-78. The majority of his data, however, deals with the Mediterranean world before the Black Death, Jewish women, or rural societies.

50 Boone, Dumon and Reusens, Immobiliënmarkt, 346-8.

51 It is worth noting that the registers of St John's hospital contain larger numbers of women paying a cens together with their husbands, which might suggest involvement of the couple's communal property. However, the share of women paying a cens independently did decline: from 21 per cent in 1356 to 9 per cent in 1409.

52 Tiffany A. Ziegler, 'I was sick and you visited me: the hospital of Saint John in Brussels and its patrons' (unpublished D.Phil. thesis, University of Missouri-Columbia, 2010), 392; David Kusman, 'Le Rôle des hôpitaux comme institutions de crédit dans le duché de Brabant (XIIIe-XVe siècles)', in Michel Pauly ed., Institutions de l'assistance sociale en Lotharingie médiévale (Luxembourg, 2008), 366-73.

53 See, for example, Boone, Dumon and Reusens, Immobiliënmarkt, 196-9.

54 See, for an overview, Herman Van der Wee, The growth of the Antwerp market and the European economy (fourteenth-sixteenth centuries), 9-18.

55 Peter Spufford, Money and its use in medieval Europe (Cambridge, 1989), 349 with 922 specific reference to Brabant; Herman van der Wee and Jan Materné, 'De muntpolitiek 
in Brabant tijdens de late Middeleeuwen en bij de overgang naar de nieuwe tijd', in 924 Henricus van den Eerenbeemt ed., Bankieren in Brabant in de loop der eeuwen 925 (Tilburg, 1987), 43-50.

56 Félicien Favresse, L'Avènement du régime démocratique à Bruxelles pendant le Moyen Age (1306-1423) (Brussels, 1932), 107-19; Claire Dickstein-Bernard, La gestion financière d'une capitale à ses débuts: Bruxelles 1334-1467 (Brussels, 1977), 112-15.

57 Free translation of 'de stad mids crancker neringen, die lange daerinne es geweest ende in lanc soe meer continueert ..., alsoe de de menichte van den volke zeer vermindert, de huyse vervallen ende andersins de voirseide stad grotelic declineert'. See Guillaume Des Marez, L'Organisation du travail à Bruxelles au XVe siècle (Brussels, 1904), 472-3.

58 This was a consequence of the history of this neighbourhood. After the guilds of the weavers and fullers were banished from the city centre due to a failed revolt in 1303, many settled in the parish of the Chapel. The inhabitants of the quarter thus came predominantly from the lower and middle groups. Claire Billen and Chloé Deligne, 'Autonomie et inclusion d'un espace: les détours de l'appartenance du quartier de La Chapelle à la Ville de Bruxelles (XIIe- XIVe siècle)', in A. Dierkens a.o. eds., Villes et villages: organisation et représentation de l'espace (Brussels, 2011), 84-7.

59 A small section of the Chapel parish, which was located within the first city wall, has been excluded from the analysis.

60 They were identified with a title, or could be linked to elite families through their names and family members.

One woman was definitely linked to Brussels patrician linages. The other woman paid a cens for no less than four houses and her husband came from an important, albeit non-patrician, family (van Bolenbeke).

62 OCMW Archive Brussels, Bienfaissance, no. 216, fos. 73r, 75r.

63 For the relationship between economic trends and real estate and capital markets in the Low Countries, see among others, Hugo Soly, 'De schepenregisters als bron voor de conjunctuurgeschiedenis van Zuid - en Noordnederlandse steden in het Ancien Régime: een concreet voorbeeld: de Antwerpse immobiliënmarkt in de 16de eeuw', Tijdschrift voor Geschiedenis 87, 1 (1974), 521-44; Boone, Dumon and Reusens, Immobiliënmarkt, 86-9.

64 The difficult economic situation of the inhabitants of Brussels has been discussed on pp. 1920. For additional discussion of the increased impoverishment in the city, see Claire Dickstein-Bernard, 'Paupérisme et secours aux pauvres à Bruxelles au XVe siècle', Belgisch tijdschrift voor filologie en geschiedenis 55, 2 (1977), 390-415. The selling of real estate by people without sufficient financial reserves during times of economic difficulties has been observed in late medieval Ghent; see Boone, Dumon and Reusens, Immobiliënmarkt, 154-6. See also, in general for the Low Countries, Raymond van Uytven, 'La Flandre et le Brabant, “terres de promission” sous les ducs de Bourgogne?', Revue de Nord 43, 3 (1961), 312-13.

65 Bram Vannieuwenhuyze and Stefan Meijering, 'Het Brusselse hof van Nassau: de oprichting 963 van een laatmiddeleeuwse stadsresidentie', Belgisch Tijdschrift voor Filologie en Geschiedenis 964 88, 2 (2010), 367. $12 \mathrm{r}$.

68 Boone, Dumon and Reusens, Immobiliënmarkt, 312-13. 969 
Répartition par sexe de la propriété immobilière à Bruxelles à la fin du Moyen Âge 972 (1356-1460)

Posséder des biens immobiliers était crucial et commode pour l'économie des femmes des villes médiévales, pourtant la répartition par sexe des biens immobiliers urbains au fil du temps a suscité peu d'études systématiques. Utilisant les censiers (type de source historique rarement utilisé), l'article aborde cette question à partir d'une analyse sociogéographique du Bruxelles de l'époque. L'auteur constate que, malgré une législation locale imposant un système d'héritage égalitaire, la part des femmes était relativement limitée en matière de propriété immobilière et même qu'elle y a de plus décliné à la fin du Moyen Âge. Cette diminution s'est accélérée pendant les crises économiques et a surtout affecté la propriété des femmes qui ne faisaient pas partie de l'élite locale. Des recherches plus poussées seraient bienvenues sur les changements intervenus au cours de l'époque médiévale, qui réduisirent, pour les femmes, l'éventail de leur potentiel économique. En particulier, un débat plus explicite serait souhaitable sur leurs sources de revenu non liées au travail et mettant en jeu leur statut social.

Die geschlechtsspezifische Verteilung des Grundbesitzes im spätmittelalterlichen Brüssel (1356-1460)

Obwohl für die ökonomischen Möglichkeiten von Frauen in mittelalterlichen Städten 988 die Verfügung über Grundbesitz entscheidend war, haben bislang nur wenige 989 Studien die geschlechtsspezifische Verteilung des Grundbesitzes im Zeitverlauf näher untersucht. Unter Verwendung von censiers (einer selten benutzte Quelle) geht der Beitrag dieser Frage in Form einer sozialtopographischen Analyse Brüssels nach. Die Untersuchung ergibt, dass trotz des egalitären Erbrechts in dieser Region weiblicher Grundbesitz vergleichsweise begrenzt war und im Spätmittelalter noch weiter abnahm. Dieser Rückgang beschleunigte sich in ökonomischen Krisenzeiten und betraf vor allem den Besitz von Frauen, die nicht der Elite angehörten. Die künftige Forschung über die Veränderungen der ökonomischen Möglichkeiten mittelalterlicher Frauen würde sicher davon profitieren, wenn sie sich starker als bisher mit den Einkommensquellen und sozialen Statusmerkmalen befassen würde, die nicht auf eigener Erwerbsarbeit beruhten. 